\title{
Foreign Languages: A Gate from the Past to the Present
}

\author{
Mahdi Dahmardeh", Amir Nemati Limaee \\ Faculty of Foreign Languages and Literature of the University of Tehran, North Kargar Avenue, \\ Tehran, Iran. \\ E-mail address: dahmardeh@ut.ac.ir; amir.nemati.limaee@gmail.com
}

Keywords: Persia, Iran, History, Foreign Languages

\begin{abstract}
Persia has got an ancient, very rich history and civilisation. This has resulted into widespread relations between Persians and other nations along history. As a result, besides the Persian language which has been used to communicate by different people settled in this territory, befitting a time and era, a variety of foreign languages have become popular. By the means of historical research, this article aims to discuss foreign languages in Persia and their changes in different eras, from the past to the present. Having considered historical documents and existing knowledge, it has been realised that the number of languages that used to be spoken during the Persian history as well as their diversity is very impressive.
\end{abstract}

\section{INTRODUCTION}

Persia is considered to be one of the oldest civilisations and because of its especial geographical and geopolitical position, economic conditions and so many other factors has always attracted the attention of rulers and people of other countries. As a result, the Persians have always been in contact with other nations; therefore, besides the Persian language (Ancient, Middle and Dari) befitting a time and era, a variety of other languages have been used in this territory. One thing is for sure though, researchers have not considered the issue of common foreign languages in Persia and their changes during its history neither have they written articles or books that would cover such an issue. In other words, whatever has been written in this regard is either about a particular foreign language such as English or Arabic or is about a limited time in the Persian history especially the modern one. Thus, it is has been decided to present a discussion, by the means of historical research, about common foreign languages in Persia and their changes in different eras, from the past to the present.

Bearing in mind the current understandings of different historical eras of Persia, it has been decided to present this article according to a framework in which each section would explain about foreign languages in that particular period within the history of Persia. The history of Persia has been divided into these parts since each period had witnessed a substantial changes in terms of political, social, economic, cultural etc. So, it might be assumed that because of such changes, substantial changes have also been occurred about what this article aims to cover.

\section{FOREIGN LANGUAGES IN ANCIENT PERSIA}

The land of Persia has got a very old history and enjoys one of the oldest civilisations in the world. The most well-known kings who used to rule in this area before the Achaemenians were the Elamites. The Elamite Empire was established in 2680 B.C. and they had continued to rule until the $7^{\text {th }}$ Century B.C. (Rajabi, 2004). Considering the language which was spoken by the Elamites as a foreign language is unfair since although it is still unclear where these people were originally from, they were natives of a land where later due to mass immigrations of Aryans was named 'Iran'. In fact, the reason behind referring to the Elamite's language is because this language used to be around and commonly used for so many years during the history of Persia. Nowadays, there are so many documents proving that this language used to be so common and widely spoken at the time. The written bricks in Ziggurat or the Elamite Temple (Choga Zanbil) are proofs to such a claim. 
There are more than five thousands bricks written in Elamite language and Cuneiform (Rajabi, 2004).

When the Achaemenians came to power in 550 B.C. the most powerful kingdom of the ancient world became into existence. Due to its vast kingdom and long borders, observing different people with their own culture, traditions and languages was quite obvious. Issues such as expanded territory, huge diversity among people, government's needs to communicate with dependent nations, etc. caused the foreign languages to receive a great attention. Although it is not clear how foreign languages were taught at the time, it is obvious that there were so many Persians who were able to speak other languages besides their mother tongue. Among these the Elamite language had an especial place and it was one of the languages that was spoken in the Achaemenian court. It is worth mentioning that hundreds of clay tablets discovered in Persepolis are written in the Elamite language. Also, the four gold and silver tablets discovered from the Apadana in Persepolis include some information written in Elamite. The so called multilingual Bisitun inscription remained from the empire of Darius the Great also includes thorough information in three languages of Ancient Persian, Elamite and Babylonian (Pirniya, 2001).

The Babylonian language is another common language at the time of Achaemenians. In many tablets and inscriptions of this era such as the tablet of the tomb of Darius in Naqsh-e Rustam, this language can be seen next to the Ancient Persian and the Elamite language. However, the most important evidence left from that time which shows the importance of the Babylonian language during the Achaemenian era is the Cyrus Cylinder. A cylinder made of baked clay which was produced by the command of the Cyrus the great including some important information written in the Babylonian (Pirniya, 2001).

One of the most important foreign languages in the Achaemenian Empire was the Aramaic language. Near end of this era, the Aramaic language became the official and international language of the Achaemenian Empire (Frye, 1976). Among many discovered clay tablets from Persepolis, hundreds of them are written in Aramaic. The discovery of some pieces of the Bisitun inscription in Elephantine (Island in Egypt) which is written on papyrus in Aramaic (Briant, 2002) is also a proof to this claim.

The Achaemenian Empire fallen down in 330 B.C. after the Alexander conquest. After the death of Alexander and many fights between his generals, in 323 B.C., one of warlords named Seleucus established the Seleucid Empire in Persia. The Seleucid kings had always tried to promote Hellenisation and Greek culture while they were in power. As a result, Greek language and script had become the official language of the administration (Mashkoor \& Rajabniya, 1995). However less than seven decades later when the Parthians came to power, a lot of efforts were made to restore the Persian identity. Using tough anti-Greek policies by Artabanus I (Wolski, 1956) and gathering written and oral archives of Avesta by Vologases I (Rajabi, 2004) were among such efforts. Despite such efforts, the influence of Greek culture in the Seleucid era especially during the first years of their reign was quite obvious. Using the Greek language as well as calling some of the Seleucid kings Philhellene (the admirer of Greeks and everything Greek) on the Seleucid coinage is proofs to such claims (Azari, 1999). As already mentioned, it could be argued that the Greek language used to be a common language at least among a group of Persians. There are also documents to prove this claim: for instance, a) a letter in Greek that was sent to the elders of Susa by Artabanus III, and b) the leather posts acquired from Hawraman in Kurdistan which were deeds about selling two gardens of grapes written in Greek and Pahlavi (Rajabi, 2004). Furthermore, there are reports saying that the Persians used to read Homer's works and the children used to recite Sophocles and Euripides (Boyce, 1991).

Another foreign language that was spoken by some people during the reign of Seleucid was the Roman language. Sorena, a well-known commander, at the time also knew how to communicate in this language (Rajabi, 2004). Phraates V (Phraataces) could also speak in Roman since her mother, Musa, was a Roman female slave (Zarrinkoob, 2005). Moreover, some of the Seleucid princes such as Vonones I had lived in Rome for a long time (Mashkoor \& Rajabniya, 1995), so it is likely that they could also speak Roman. 
At the time of Seleucid Empire the Aramaic language was still being widely used by the Seleucids. For a while, they were benefiting from Aramaic scripts in order to write in Pahlavi (Pirniya, 2001). Many discovered documents from one of the Seleucid capitals, Nesa city (in modern Turkmenistan), proves this claim.

The Sasanian Empire was founded by Ardashir I, after the fall of the Parthian Empire and the defeat of the last Arsacid king, Artabanus V in 224 A.D. One of the foreign languages used to communicate during the Sassanid period was the Syriac language. It is worth mentioning most of Mani's major works in which he had invited people to a new religion at the time of the Sassanid king, Shapur I, was in Syriac (Christensen, 1935). The Greek language was also a bit popular at this time. Greek scripts on the Shapur I inscription on the Kaaba of Zoroaster can be used to support the idea (Frye, 1975). Teaching Greek knowledge at the University of Gundeshapur as well as translating many Greek works into the Syriac and Pahlavi language (Najm Abadi, 1966) would show that there were people among Persians who knew the Greek language. Besides, at the time of kingdom of Khosrau I, some Greek philosophers took refuge in Persia. Khosrau I welcomed them with open arms and put them in charge of teaching at the University of Gundeshapur. Pryskyanvs was one of these philosophers who wrote a book in Greek language answering questions raised by Khosrau I (Rajabi, 2004).

The Indian language was also in the centre of attention during the reign of the Sassanians. Some of Indian scholars used to teach at the University of Gundeshapur. By the command of some Sassanid kings, so many valuable Indian books were translated as well (Dorrani, 1997). Borzuya the physician was one of the most skilful translators of Indian works during the Sassanid period. He had to travel to India on the command of Khosrau I and managed to transfer many Indian books to Persia. He translated the Indian Panchatantra from Sanskrit into Pahlavi (Christensen, 1935). Like the time of the Seleucids, during the Sassanid period the Roman language was also important since the Sasanians like the Seleucids were always in contact and had business with the Romans.

\section{FOREIGN LANGUAGES IN THE ISLAMIC PERIOD (FROM THE ARAB TO THE MONGOL INVASIONS)}

After the arrival of Islam and Arab conquests, Persia had become part of the widespread Islamic state. The language that was so common and used by majority of people across the Islamic territory including Persia was Arabic. It was during the time of Abbasid Caliphate when first signs of the establishment of an Islamic civilisation became apparent. A civilisation that has achieved a development and advancement in terms of science and knowledge as well as other fields within a very short period of time. Such an advancement has roots in a phenomenon that today experts call it the Translation Movement. A movement in which professional translators translated written works by many nations into Arabic. Because of such a movement Muslims have become heirs of many ancient civilisations like India, Egypt, Persia, Greece, Rome etc. The House of Wisdom in Baghdad was a gathering place for many scholars who were responsible for the translation. So many scholars of this marvellous library were Persian. According to Jurji Zaydan (1902), a well-known Arab writer, the House of Wisdom was founded by the Persians, managed and organised by them and most of those who visited and went to the place were from Persia. It is further worth mentioning that Persians managed to write not only masterpieces in Arabic but also some of them like Abu Ali Seibooye and Abu Ali Farsi could write the most comprehensive Arabic grammar books (Jamshidnejad, 1997). Persian scholars' interest in writing in Arabic continued even after ending the Caliphate and the establishment of Persian kingdoms. Although the number of works written in Persian since the early years of Islamic era is quite high, the number of works written in Arabic by the Persians is still outstanding. The presence of Persian scholars who wrote their works in Arabic such as Avicenna, Zakariya al-Razi, Abū Rayḥān al-Bīrūnī, Khayyám etc. is a proof to such a claim.

The Turkish language was another language that was a bit around in this era. That is because it was during this period that many Turkish tribes had moved to Persia and established some kingdoms over there. However, the Turkish language was never used within the administrations, 
and scientific and literary domains during this period of Persian history. Absence of written works in Turkish during this period is a good way to support the claim. However, some people argue that book of Dede Korkut could be used to support the idea that the Turkish language was used for writing during this period of the Persian history but today researchers do not agree about date and place where the book had been written.

\section{OREIGN LANGUAGES IN THE MONGOL AND TIMURID PERIODS}

In 1219, Genghis Khan managed to invade Persia by using heavy force. The very first foreign language that could get into Persia at this time was Mongolian. The discovered coinage from that period could be used to support this idea. Apparently, the use of Mongolian can be seen on the minted coins under the Il-Khan rulers like Hulagu Khan and Arghun Khan (Bayani, 2008). It is worth mentioning that some of the intellectual elites especially those who had an influence and connection in the system knew this language (Spuler, 1988). One of these people was Khaje Rashid Al-din Fazl Allah Hamedani, an intellectual and a politician, who benefitted from many of Mongolian literatures and resources in order to write his masterpiece, Jāmi al-tavārīkh (Iqbal Ashtiyani, 2000). The well-known historian at the time of Mongols, Khaje Ata-Malik Juvayni, also had known the Mongolian. That is because he used Mongolian literatures and resources in order to write his famous book named Tarikh-i Jahangushay (Bayani, 1971).

The Turkish language became more popular during this period. That is because many Turkish tribes had allied themselves with the Mongols during the attack on Persia; therefore, so many of them moved and settled in Persia after the invasion (Bayani, 2008). It has to be borne in mind that many parts of Western Asia including Azerbaijan have changed their language into Turkish because of the alliance between Turks and Mongols during the reign of Il-Khan rulers. However, it was too early for the Turkish language to become common for writing as well as using in literary and scientific books.

After the establishment of the Timurid dynasty in 1370 A.D. the influence of Mongolian was disappeared from Persia. As Mongols lost the power, there was no need for the Persians to learn the language anymore. The most important linguistic event during the ruling of the Timurids was the widespread of the Turkish language. It was then that for the first time, writing and composing poems in Turkish became common. Scholars like Gedaee, Naqibi, Lotfi Haravi and literate princes like Khalil Sultan, Eskandar Mirza etc. took the first steps in this regard (Farhani Monfared, 2003). Although the person who made a great contribution to the role of Turkish by writing and composing poems in this language was Ali-Shir Nava'i, poet, writer, politician, linguist, mystic and painter. While Ali-Shir Nava'i was fluent in both Persian and Turkish and managed to write books and articles in both languages but his works are mostly in Turkish. In order to reinforce the Turkish language, he even wrote a book named Muhakamat al-Lughatayn in which he made a controversial claim stating that the Turkish language is superior to the Persian language, although he supported his claim by weak and unreliable proofs. It is worth mentioning while the Turkish language had become so developed during the Timurid dynasty, but the official language of the country as well as the administration was always Persian.

Both during the period of Mongols and Timurids, the Arabic language was in the centre of attention by the Persians and those who wished to learn how to read and write and also continue their education had to learn Arabic first. However, the number of written works by Persians in Arabic during these periods had decreased slightly comparing the earlier eras and majority of works were written in Persian. It might be argued that during these periods probably Persians had used the Arabic language only in order to write about religious materials. Although, so many works in theology and related fields have been left from these eras which are written in Persian.

\section{FOREIGN LANGUAGES IN THE SAFAVID, AFSHARID AND ZAND PERIODS}

When the Safavid dynasty had come to power in 1501 A.D., Persia witnessed many changes in terms of common foreign languages. The very first change was a boom in learning and teaching 
the Arabic language. The reason behind this was because the Safavids were aiming to expand the Shia practice more than ever in their territory; therefore, they invited Shia clerics to join them from Jabal Amel, Lebanon, which was a centre for Shia groups at the time (Farhani Monfared, 1998). The migrated clerics not only had written many books in Arabic but also their presence encouraged the Persian scholars to use this language in their works more than ever. Works by Mulla Sadra, Bahā' al-dīn al-'Āmilī, Mir Damad could be used as examples in Arabic.

The Turkish language had also experienced a boom during the Safavid dynasty. This language was used as a spoken language among the Safavid rulers since they came to power by the support that they had received from seven Turkish tribes. The founder of the Safavid dynasty, Ismail I, was a poet composing poetry in Turkish. It has to be borne in mind, although the Turkish language at this time used to be the mother tongue for many people especially in Azerbaijan, it was only used as a means of communication (speaking only) and only among a few groups of Persians. A review of the left documents from the Safavid dynasty which are mainly in Persian and also lack or rare number of documents and works in Turkish could be used as a support to this claim.

The Armenian language was also among those foreign languages that had existed in this time. During this period big groups of Armenians were forced to move into the central parts of Persia and this caused an acquaintance between Persians and Armenians as well as their language. However, this language was only used among the Armenians themselves and the Persians never felt a need to communicate in this language. The works written in Armenian during this period, mostly religious documents, (Karimiyan, 2006) were only studied by the Armenians themselves.

It was during the Safavid dynasty that many Georgians also forced to move to Persia by the Safavid kings. Presence of the Georgians resulted into an appearance of another foreign language but this one also was like the Armenian only limited to be spoken among the Georgians themselves. The Georgians never tried to write anything in their language. Resaleye Shenakht which is a book on education and religion and was written in Georgian could be considered as an exception though. The identity of the author of the book which is a poetry one is unknown; however, one thing is for certain that he/she was a Georgian who converted to Islam and used to live at the time of the Safavids.

In terms of foreign languages during the Afsharid and Zand Periods that were following the falling of the Safavid dynasty, the situation was quite similar to the preceding period and there is nothing noteworthy to mention.

\section{FOREIGN LANGUAGES IN THE QAJAR DYNASTY}

Agha Muhammad Khan came to the throne in Tehran and established the Qajar dynasty in 1795 A.D. This reign was contemporaneous with many changes across the world. The beginning of colonisation era, European states competition to expand their influence across the world, beginning of the Modernism, The Industrial Revolution, The French Revolution, The First World War, The Russian Communist revolution etc. were among a few number of events that happened during the Qajar period. These events had resulted into an increase in relations and interactions between Persia and the West and therefore the political, cultural, economic, military etc. relations were increased dramatically. Since the Arabic and Turkish languages did not experience a huge difference comparing the previous era, it would be a repetitive task to talk about them during this period; however, it is worth mentioning that the status of other foreign languages in general experienced a substantial changes comparing the previous eras since at this time using European languages became so common among Persians. Besides what mentioned above there were two main reasons behind the popularity of Western languages among Persians:

\section{a. Sending Students Abroad}

It was at this time when those who were in charge as well as the Qajar rulers had realised the outstanding advancement of the West and their weakness so they decided to learn new and latest science, knowledge and technology from the West who owned it by then. As a result, so many groups by the government were sent out to the West to learn the latest knowledge (Nemati, 2009). 
During the Qajar dynasty, this process continued to happen frequently. Furthermore, many Persian families who were rich enough started to send out their children for education abroad (Hazeri, 1993). It is obvious how much these graduates returned home could influence on an increase in the prevalence of western languages.

\section{b. Western Missionaries and the Establishment of Modern Educational Centres}

Contemporaneous with the increase of relations between Persia and the West, the process of arrival of western missionaries and other western religious clerics which had been started from the time of Safavids was accelerated substantially. They managed to establish variety of schools across the country and could also grow learning foreign languages in Persia significantly. Founding a school by Justin Perkins, an American Presbyterian missionary in Oroomiah (Borjian, 2013), founding a school in Isfahan by Robert Bruce, a member of British Church Missionary Society (Varham, 2006), founding Tehran Vincent de Paul School by French Lazarist Catholics (Varham, 2006) are few examples for this movement. Some of the Persians also started founding new schools by applying European educational systems. Haji-Mirza Hassan Roshdieh was the first one who started founding such schools (Dorrani, 1997). Centres for higher education studies had also become established similar to their western counterparts for the first time during the Qajar dynasty. Dar ul-Funun was the very first kind of such institutes founded by the very popular chief minister to Naser al-Din Shah Qajar, Amir Kabir, in Tehran (Varham, 2006). Moshiriyeh School that was founded by the well-known Qajar politician and translator, Muhammad Hasan Khan Etemead AlSaltaneh, in order to teach foreign languages such as English, French and Russian and also to train professional translators is another centre for higher education studies during the Qajar dynasty (Karimiyan, 2006).

To conclude, it is worth mentioning that among all the common foreign languages in Persia in this period, French was the predominant one even more than English and Russian (Borjian, 2013). That is because of slightly higher number of students who went to France to continue their education (Hazeri, 1993), language of instruction at Dar ul-Funun which was French (Varham, 2006) as well as some other reasons.

\section{FOREIGN LANGUAGES IN THE PAHLAVI AUTOCRACY}

By the ending of Qajar dynasty in October 1925, the Pahlavi Autocracy was established. During this period, the number of Iranians who were fluent in foreign languages was increased due to some reasons such as the efforts made by the Pahlavi kings to modernise the country, new changes that had occurred across the globe, a substantial increase in the world communication. The linguistic changes at the time of Pahlavi comparing to their Qajar predecessors was quite different in two terms. First of all, during the Pahlavi period learning foreign languages was not limited only to Arabic, French, English and Russian. On the other hand, Iranians due to some reasons decided to learn other languages. Second of all, the English language during the Pahlavi Monarchy became more important and finally during the reign of Muhammad Reza Pahlavi the French language was replaced by the English language. The reason for this lied behind the fact that after the end of Second World War, America as an English speaking country was recognised as one of the two superpowers in the world. The close relation between Iran and America especially after the $19^{\text {th }}$ August 1953 Coup in Iran as well as huge increase in the political, economic, scientific and trade relations between two countries have resulted into the replacement of French by the English language. Generally, besides what has been said so far, followings could also be considered as important factors that have caused the linguistic changes during Pahlavi period.

\section{a. A Huge Increase in Sending Students Abroad}

Iran during the reign of Pahlavi experienced a huge increase in sending students abroad. According to Ashna (2005) and Khajavi \& Abbasian (2011), the number of Iranian students who were studying in American universities in 1977 was about 23000 people. 


\section{b. Establishment of Universities and Modern Educational Centres}

The policy of establishing new schools and centres for higher education studies had started in Qajar period continued to run a lot faster at this time. Founding the University of Tehran could be considered as the most outstanding example of this trend which happened at the time of Reza Shah Pahlavi. So many universities were also founded during the reign of Muhammad Reza Pahlavi. One of the good examples would be Shiraz Pahlavi University (currently known as Shiraz University) which was founded based on American universities model. The language of instruction at this university used to be both in English and Persian.

\section{c. Institutes and Cultural Councils}

During the reign of Pahlavi especially at the time of Muhammad Reza Pahlavi, many institutes and cultural councils have started their activities in Iran resulted into an increase in teaching and learning foreign languages, English in particular. One of these examples would be the Iran-America Society established in 1955 (Borjian, 2013) and became the most important cultural base for America in the world during its fifty-year activity (Bill, 1989). Another institute is the British Council that founded its first branch in Iran in 1942. The priority of the council was to teach the English language and managed to teach English to thousands of Iranians (Encyclopaedia Iranica). The Iran-Soviet Union Society of Cultural Relations founded in 1943 (Nafisi, 1944) could be used as another example. Establishing a commission comprising of professional translators who were fluent in both Persian and Russian as well as holding language courses for teaching the Russian language were among the activities of this society. The Goethe-Institut, is the biggest nongovernmental cultural institute that has started its work in Iran during the Pahlavi era. During the reign of Muhammad Reza Pahlavi, the institute managed to teach the German language to hundreds of Iranians (Aryan pour, 1974). Shokouh English Institute founded by Dr Mohsen Shokouh in 1950 is another private centre that has a long history of teaching the English language in Iran. Just before the Islamic Revolution of 1979, Shokouh was one of the most popular and active centres for the English language in the nation, with around 60 branches (Borjian, 2013).

\section{FOREIGN LANGUAGES IN POST-REVOLUTIONARY IRAN}

In $11^{\text {th }}$ February 1979, the Pahlavi Autocracy collapsed and was replaced by the Islamic Republic. During the early years of the revolution, because of the situation as well as the new rulers' ideological differences with the bipolar world at the time, the speed of language learning especially learning the English language decreased dramatically. This could be further discussed by the fact that what the Islamic Republic and its rulers had in mind was in total contrast with what the Western and Eastern Blocs were claiming. Due to this fact, during the early years of the revolution it would be typical to see objections to whatever that could encourage or advertise foreign ideologies.

Despite this, after a short while from the founding of the Islamic Republic the old trend of foreign language learning and teaching started to follow gradually though. During the Islamic Republic, due to variety of reasons although some Iranians would like to learn different languages or even those which are less known, the English language is still the most popular language among the Iranians and its popularity is the same as the Pahlavi period or it could be claimed even more.

Furthermore, learning the Arabic language which has always been favoured by the Iranians due to traditional Iranian-Islamic belief, has become more powerful than ever in this era. This is because the rulers of the Islamic Republic have always supported the Arabic since the policy of the state has been encouraging the nation to be religious, propagating Islam, making efforts to export the revolution etc. In fact, raising the quality as well as quantity of religious schools across the country, selecting the Arabic language as one of the main courses to be taught at secondary schools, publishing Arabic newspapers and magazines such as Alvefagh Newspaper affiliated with the Islamic Republic News Agency, establishing Arabic channels like Al-Alam and iFilm by the IRIB, 
etc. are just few examples that are part of the policy of the Islamic Republic to promote the Arabic language.

Of course, the Islamic Republic has established many other channels and published many other newspapers in other languages as well. Some examples are: Press TV channel in English; Hispan TV channel in Spanish; Sahar channel which broadcasts in English, French, Urdu, Bosnian etc.; international radio channels which broadcasts programmes in Russian, English, Turkish, French etc.; English language newspapers like Iran Daily, Tehran Times, Kayhan International and French magazine La Revue de Téhéran which is published monthly.

Some of the main reasons behind the process of promoting foreign language learning among the Iranians during this period are:

\section{a. The Continuation of Sending Students Abroad and an Increase in the Number of Universities}

The Islamic Republic has not stopped any of Iranians from leaving the country to continue their education and the process still continues. In the early years of the revolution like the Pahlavi Era, most of the students used to go to countries like American and Great Britain (Hazeri, 1993); however, later on the destinations has not been limited to these two countries or France and Germany. Although there are so many people who still choose these countries as their destination to pursue higher education, there are also many people who would choose other countries such as Romania, China, India, Philippine, Turkey, Finland, Switzerland, Belgium, Australia, New Zealand, Pakistan, etc. (Hazeri, 1993) in order to continue their education. There is no need to further point out how much this could have affected the promotion of foreign languages in modern Iran.

Between 1980 and 1987, the Islamic Republic witnessed a cultural revolution. This was a period following the Iranian Revolution where the academia of Iran was purged of Western and non-Islamic influences to bring it in line with Shia Islam. Directed by the Cultural Revolutionary Headquarters and later by the Supreme Cultural Revolution Council, the revolution closed universities for three years (1980-1983). Although this action was taken by the government, it has to be pointed out that during the Islamic Republic the number of universities have been increased substantially but not necessarily in terms of quality. The Islamic Open University (Azad Eslami) founded in 1982 might be considered as a good example to support this claim. This university with hundreds of branches working inside and outside of Iran and its huge campuses as well as its increasing number of students could be considered as the biggest university in the world (Farhady et al., 2010).

The growth in the number of universities has resulted into the increase of foreign language learning, English in particular and this could be studied from two aspects. First of all, all the university students are required to pass between 2 and 5 units of English language no matter what level or discipline they study. Secondly, in majority of the Iranian universities, departments of foreign languages have been established which they do offer B.A., M.A. and $\mathrm{PhD}$ courses in foreign languages. For instance, the Faculty of Foreign Languages and Literature of the University of Tehran has got departments of English, Urdu, French, Spanish, German, Italian, Russian and Japanese. Moreover, Allameh Tabatabai University, one of the universities founded after the revolution, has got departments of English, Spanish, French, Russian, Chinese, Arabic and Turkish. Furthermore, it is worth mentioning that in many of the Iranians universities, centres for teaching foreign languages have been established too. The most important one in the country is the University of Tehran Language Centre. Founded in 2000, the centre started its work by presenting 7 foreign languages. In 2011, due to changes of policy and administration the number of languages have been increased to 34 languages. Some of the languages that are currently taught are: English, French, German, Russian, Italian, Spanish, Polish, Dutch, Turkish, Korean, Japanese, Chinese, Georgian, Greek, Armenian, Ancient Persian, Middle Persian, Urdu, Hindi, Swedish, Latin, Portuguese, Ancient Greek, Sanskrit, Avestan, Malay, Indonesian, Swahili, Vietnamese, Hausa, Aramaic, Arabic, Hebrew etc. 


\section{b. Schools}

During the Islamic Republic like the previous period, pupils are required to study the English and Arabic language all across the country. These languages are offered by schools as a compulsory subject and pupils must study both of them for a few hours every week at school. Although some researchers argue that the policy makers of Iran have tried to replace other foreign languages like German, Russian, French, Italian and Spanish with the English language (Frahady et al., 2010). Even if such a claim would have been true, the English language is still considered as one the main foreign languages within the Iranian National Curriculum and those who wish to study other languages must either attend very few schools that offer such courses or alternatively they could learn the language at private institute for which they would not receive any credit as part of the Iranian educational system and their schools programmes.

\section{c. Foreign Cultural Institutes, Academies, Modern Media}

For a few years after the foundation of the Islamic Republic, foreign institutes were facing some limitations to operate; however, this does not mean that today there is no foreign institute operating in Iran. In fact, currently some cultural institutes affiliated with other countries do operate in Iran and some of the most famous ones are: Goethe Institut, Austria Cultural Society, and France Language Centre. The British Council also used to operate in Iran between 2001 and 2009.

Besides the above mentioned foreign institutes, currently there are so many private and public academies with many branches across the country which play an important role in teaching foreign languages. Among the most famous ones are Jahad Deneshgahi Language Centre, Iran Language Institute, Kish Language Institute and Shokouh Institute.

Appearance, spread and progress of new telecommunication technologies have played an important role in making Iranians familiar with foreign languages and the English language in particular. For instance, appearance of the satellite channels and becoming part of Iranian family, although it is still illegal by the government, and the fact that they are mostly in English and play movies in the same language as well, the movies which are mainly produced in America, directly or indirectly encourage the viewers to learn the English language (Khajavi \& Abbasian, 2001). So many people also use the new telecommunication technologies in order to receive the latest world news or watch documentaries about sociology, biology, economics, history, military etc. and these different tastes have resulted into gaining more understanding and knowledge about foreign languages and the vital need to learn at least one. To get used to work with computer and the Internet especially by the Iranian youths and having a fair knowledge of English which is a prerequisite for the best performance has been another factor too. One thing is for sure. Using the Internet has caused a great change among Iranians and the way that they would come across to jargons in business and commerce, education, science, technology, etc. Most of the time, understanding these jargons requires a fair knowledge of the English language (Mojtahedzadeh \& Mojtahedzadeh, 2012).

\section{CONCLUSIONS}

As mentioned in the introduction, this article aims to study foreign languages in Persia and their changes in different eras, from the past to the present. The researchers hope that the presented discussions in different sections of the article could have given a fair understanding, if not a thorough one, about the foreign languages in Persia in different periods and fulfil the aim that the authors had in mind. So, this section is not going to bore the readers by repeating what has already been mentioned. However, in a nutshell it could be argued that the Persian history has witnessed various languages used to be in circulation as well as their changes over time. In fact, it might be argued the variety of languages that used to be spoken by the Persians and the reasons why they have always tried to use them throughout history is so splendid in a way that we may never find any country or nation across the world which has experienced such a situation. 


\section{References}

[1] Aryan pour, A. A. (1974). 500 Years of relation between Iran and Germany. Journal of Art and People, 146, 37-59.

[2] Ashna, H. (2005). Annals of American cultural diplomacy in Iran. Journal of Historical Studies, 9, 46-69.

[3] Azari, A. (1999). A Mention to the cultural relation between Persia and Greece during the Parthians. Journal of Faculty of Literature and Humanities of the University of Tehran, 148, 7-13.

[4] Bayani, Sh. (1971). Studying Persia's social condition within Jāmi al-tavārīkh: A Collection of research speeches about Rashid Al-Din Fazl-Allah Hamedani. Tehran: The University of Tehran Press.

[5] Bayani, Sh. (2008). A Window to the history. Tehran: Asatir Press.

[6] Bill, J. A. (1989). The Eagle and the lion: The Tragedy of American-Iranian relations. New Heaven: Yale University Press.

[7] Boyce, M. (1991). A history of Zoroastrianism. v.3, Zoroastrianism under Macedonian and Roman rule. Leiden: E.J. Brill.

[8] Borjian, M. (2013). English in Post-Revolutionary Iran. Bristol: Multilingual Matters.

[9] Briant, P. (2002). From Cyrus to Alexander: A History of the Persian Empire. Winona Lake, IN: Eisenbrauns.

[10] Christensen, A. (1935). L'Iran sous les Sassanides. Copenhagen: Ejnar Munksgaard.

[11] Dorrani, K. (1997). The History of education in Iran, before and after Islam. Tehran: SAMT.

[12] Farhady, H., Hezaveh, F. S. \& Hedayati, H. (2010). Reflections on foreign language education in Iran. The Electronic Journal for English as a Second Language, 13 (4), 1-18.

[13] Farhani Monfared, M. (2003). Shia clerics' migration from Jabal Amel to Persia during Safavid reign. Tehran: Amir Kabir Press.

[14] Frye, R. N. (1975). The Cambridge history of Iran. Vol.4, The period from the Arab invasion to the Saljuqs. London (etc.): Cambridge University Press.

[15] Frye, R. N. (1976). The heritage of Persia. London: Cardinal.

[16] Hazeri, A. M. (1993). Process and trends of sending students abroad in Iran. Tehran: SAMT.

[17] Iqbal Ashtiyani, A. (2000). History of Mongols. Tehran: Amir Kabir Press.

[18] Jamshidnejad, Gh. (1997). Andelosi, Qazi Saeed, Al-Tareef Be Tabaqat Al-Omam. Tehran: Hijrat Press.

[19] Karimiyan, A. (2006). The History of printing and printing house in Iran. Ketab Mah Koliyat, $103,32-39$.

[20] Khajavi, Y. \& Abbasian, R. (2011). English language in Iran: Why Practice is more common than practise? Canadian Social Science, 7 (4), 89-94.

[21] Mashkoor, M. J. \& Rajabniya, M. (1995). Political and social history of Parthians. Tehran: Donyaye Ketab Press.

[22] Mojtahedzadeh, M. \& Mojtahedzadeh, R. (2012). The Role of English Language Teaching and Learning in Iran. International Journal for Quality research, 6(2), 125-130.

[23] Nafisi, S. (1944). The Iran-Soviet Union Society of Cultural Relations. New Message, 1, 5261. 
[24] Najm Abadi, M. (1966). The University of Gundeshapur. Mehr, 12 (6), 398-404.

[25] Nemati, A. (2009). Cooperation and rivalry of traditionalists and modernists during the Persian Constitutional Revolution. Foruzesh, 3, 20-30.

[26] Pirniya, H. (2001). The History of Ancient Persia. Tehran: Donyaye Ketab Press.

[27] Rajabi, P. (2004). Lost Millenniums. Tehran: Iqbal Press.

[28] Spuler, B. (1988). Der Islam. 65, 166-69.

[29] Varham, Gh. (2006). Political system and social organisations in Iran in Qajar. Tehran: Moeen.

[30] Wolski, J. (1956). The Decay of the Iranian Empire of the Seleucids and the Chronology of the Parthian Beginnings. Berytus, 12, 35-52.

[31] Zarrinkoob, A. (2005). The History of Iranians. Tehran: Amir Kabir Press.

[32] Zaydan, J. (1902). History of Islamic Civilisation. Kitab Bhavan. 